STUDIA PRAWNO-EKONOMICZNE, T. CX, 2019

PL ISSN 0081-6841; e-ISSN 2450-8179 $\quad$ s. 287-312

https://doi.org/10.26485/SPE/2019/110/16

\title{
Agata SZYMAŃSKA*
}

\section{THE ROLE AND IMPORTANCE OF INDEPENDENT FISCAL INSTITUTIONS IN BUDGETARY FRAMEWORKS: AN OVERVIEW}

\begin{abstract}
(Summary)
The aim of this study is to present the concept of independent fiscal institutions (IFIs) and their most important features. The analysis is amplified by the presentation of IFIs and their features gathered in datasets prepared by supranational organizations (the IMF, OECD, and European Commission). The study also provides a general analysis of IFIs in the EU. The measure of the scope of tasks discharged by selected European IFIs is presented in the form of the Scope Index of Fiscal Institutions, calculated by the European Commission. In 2016 the value of the index, calculated for 30 institutions operating in 27 EU countries, ranged from 20 (in Poland and Slovenia) to 77.14 (in the UK). The results indicate differences in the assessment of the scope of these institutions in the EU. The theoretical analyses are extended by investigation into the relations between the quality of IFIs and the situation in public finances in selected European Union countries.
\end{abstract}

Keywords: European Union; fiscal council; independent fiscal institution

Classification JEL: E62, E69

\section{Introduction}

The concept of national fiscal governance (or domestic fiscal frameworks) refers to those "rules, regulations and procedures that influence how budgetary policy is planned, approved, carried out, monitored and evaluated"1. It includes, among others, national numerical fiscal rules, medium-term budgetary frameworks, and

* Ph.D., University of Lodz, Institute of Economics; e-mail: agata.szymanska@uni.lodz.pl

1 What is fiscal governance?, https://ec.europa.eu/info/business-economy-euro/indicators-statistics/economic-databases/fiscal-governance-eu-member-states/what-fiscal-governance_en; accessed on 31.08.2018. 
independent fiscal institutions (IFIs). Independent fiscal institutions should be understood as agencies other than the central bank, government, or parliament which prepare macroeconomic forecasts or monitor public finances ${ }^{2}$. These institutions were first adopted in the Netherlands (1945), Denmark (1962), Austria (1970), the US (1974), and Belgium (1989) ${ }^{3}$. In recent years they have become a more extensive feature across many countries. The growing role of independent fiscal institutions is evident in many countries, mainly due to their impact on fiscal performance and the execution of budgetary processes.

\section{Definitions and key features of independent fiscal institutions}

Independent fiscal institutions, in general, are "independent public institutions with a mandate to critically assess, and in some cases provide non-partisan advice on, fiscal policy and performance"4. These institutions are commonly called independent parliamentary budget offices or fiscal councils ${ }^{5}$. The role of IFIs should be aimed at "providing the time-consistent, high quality analytical outputs" and increasing the effectiveness in promoting transparency in public finance and improving accountability. IFIs are primarily financed by public funds, but are functionally independent of fiscal authorities ${ }^{7}$.

$X$. Debrun et al. ${ }^{8}$ distinguish between two distinct models of independent public bodies (which they call "independent fiscal agencies"): Independent Fiscal Authority (IFA) and Fiscal Council (FC). This typology is based on the scope of mandate of independent fiscal agencies and their "modus operandi". IFAs receive the mandate to decide on specific aspects of fiscal policy. These bodies can set targets for both short-term (e.g. annual targets for budget balancing) and long-term (in the case of fiscal objectives) perspectives. Consequently, these

2 European Commission, Fiscal rules, independent institutions and medium-term budgetary frameworks, Public Finances in EMU - 2009, p. 93.

3 X. Debrun, X. Zhang, V. Lledó, The Fiscal Council Dataset: A Primer to the 2016 Vintage, IMF, 2017, p. 5.

4 L. von Trapp, I. Lienert, J. Wehner, Principles for independent fiscal institutions and case studies, OECD Journal on Budgeting 2016/15 (2), p. 11.

Ibidem.

6 L. Jankovics, M. Sherwood, Independent fiscal institutions in the EU member states: The early years, European Economy Discussion Paper 2017/067, p. 7.

European Commission, op. cit., p. 93.

8 X. Debrun, D. Hauner, M.S. Kumar, Independent Fiscal Agencies, Journal of Economic Surveys 2009/23. 
institutions can shape fiscal policy in a direct way. However, as mentioned by the authors at present these institutions are not widespread, probably due to the fact that policymakers are reluctant to provide IFAs with a significant share of their mandate. Alternatively, FCs can influence fiscal policy more indirectly - by independent advice, forecasting and projections, or independent analyses. Consequently, the authors distinguish between three types of FCs: the first type provides objective analysis (e.g. fiscal position, the macroeconomic context, and long-term sustainability); the second type provides independent projections and forecasts (related to budgetary variables as well as macroeconomic conditions); and the third type provides a normative assessment (e.g. the appropriateness of fiscal policy or relevant recommendations) ${ }^{9}$.

As mentioned above, IFIs can operate in the form of fiscal councils (FCs). A general definition of fiscal council states that it is "a publicly funded entity staffed by non-elected professionals mandated to provide non-partisan oversight of fiscal performance and/or advice and guidance" ${ }^{\prime \prime}$. The definition by X. Debrun et al. ${ }^{11}$ provides that an FC is "a permanent agency with a statutory or executive mandate to assess publicly and independently from partisan influence government's fiscal policies, plans and performance against macroeconomic objectives related to the long-term sustainability of public finances, shortmedium-term macroeconomic stability, and other official objectives". The authors also point out that FCs can perform one or several of the following functions: "(i) contribute to the use of unbiased macroeconomic and budgetary forecasts in budget preparation (through preparing forecasts, or proposing prudent levels for key parameters), (ii) identify sensible fiscal policy options, and possibly, formulate recommendations, (iii) facilitate the implementation of fiscal policy rules, and (iv) cost new policy initiatives"12.

Public audit institutions operate in some countries; however in many cases they are not strictly independent fiscal institutions per se, due to their principal functions. In the case of audit institutions, although they are independent their role is to prepare detailed ex-post analyses of each public sector entity, whereas the role of IFIs is to "maintain discipline and transparency in public finances

9 Ibidem.

10 R. Hagemann, Improving Fiscal Performance through Fiscal Councils, OECD Economics Department Working Papers, No. 829, OECD Publishing, Paris 2010, p. 5.

11 X. Debrun, T. Kinda, T. Curristine, L. Eyraud, J. Harris, J. Seiwald, The Functions and Impact of Fiscal Councils, IMF Policy Paper 2013, p. 8.

12 Ibidem. 
during the policy-making process" ${ }^{13}$ and to increase the credibility of government by real-time analysis and forecast by employing a "forward-looking diagnostic task"14. The differences between a fiscal council and audit institution are also emphasized by X. Debrun et al. ${ }^{15}$ They argue that the work of a fiscal council is macroeconomic in nature, whereas the work of an audit is mainly of a legal and more micro-economic nature. Moreover, the main tasks of fiscal councils are related to the planning and policy-formulation stage, while audits are aimed at providing ex-post evaluations ${ }^{16}$.

In 2014, the OECD council adopted the Recommendation of the Council on Principles for Independent Fiscal Institutions ${ }^{17}$. This document provides 22 principles for countries which have established or are considering establishing an IFI. These principles are grouped under nine broad headings: local ownership; independence and non-partisanship; mandate; resources; relationship with the legislature; access to information; transparency; communication; and external evaluation. The principles are aimed at strengthening the core values that IFIs promote and are related to the key features of these institutions, in particular independence, non-partisanship, transparency and accountability ${ }^{18}$. The principles demonstrate operational and technical competences, as well as other aspects related to communication with the public or public scrutiny ${ }^{19}$.

\section{Independent fiscal institutions - main datasets}

Comparable information about IFIs is presented by many institutions all over the world. The most important databases are those reported by the IMF, OECD and the European Commission.

In 2014 the IMF published the first FC dataset. It presents fiscal councils established by IMF members ${ }^{20}$. The report comprised $29 \mathrm{FCs}$, consistent with

13 G. Kopits, Independent Fiscal Institutions: Developing Good Practices, OECD Journal on Budgeting 2011/11 (3), p. 2.

14 Ibidem.

15 X. Debrun, T. Kinda, T. Curristine, L. Eyraud, J. Harris, J. Seiwald, op. cit.

16 See ibidem, p. 9.

17 Recommendation of the Council on Principles for Independent Fiscal Institutions, OECD, 2014.

18 Ibidem.

19 L. von Trapp, L. Lienert, J. Wehner, op. cit.

20 R. Beetsma, X. Debrun, X. Fang, Y. Kim, V. Lledó, S. Mbaye, X. Zhang, Independent Fiscal Councils: Recent Trends and Performance, IMF 2018, WP/18/68, p. 4. 
the main OECD's Principles for Independent Fiscal Institutions ${ }^{21}$. The latest IMF dataset (Fiscal Council Dataset) describes key features of 39 institutions established by members of the IMF. The councils included in the updated dataset comprises 15 new independent fiscal councils (IFCs) which were operational in 2016, while five IFCs from the original dataset were removed due to the lack of fulfilment of the criteria for inclusion in the datase ${ }^{22}$. The institutions included in the IMF dataset demonstrate that there has been a growing trend in establishing FCs following the global financial crisis. This phenomenon has been evident mainly among the EU countries. As reported, 11 out of the 39 analyzed IFCs were named as "veteran" i.e., the IFCs operated before the global financial crisis (before 2007). The updated IMF dataset comprises, among others, the following features of each FC under consideration: coverage; the date of creation or major reforms; an evaluation of the ex-ante analysis, ex-post evaluation, and key features related to the human resources; independence; and the role of FC in budget process.

The OECD Network of Parliamentary Budget Officials and Independent Fiscal Institutions (PBO-IFIs) provides the dataset of key features of IFIs in OECD countries. The PBO-IFIs aim at improving the budget process and evolving the role of IFIs. The latest list consists of 32 institutions operating in 26 countries, including 25 institutions in 20 EU Member States. The dataset also includes the European Fiscal Board as a separate institution. The list of 33 analyzed institutions is presented in the table below. Each institution is analyzed from the point of view of the principles, and takes into account, the OECD Principles for IFIs presented in the previous section.

Another big dataset is provided by the European Commission. On the basis of a questionnaire issued to each country, the EC services calculate the Scope Index of Fiscal Institutions (SIFI) for selected bodies. The latest data of the index (SIFI values for the year 2016) covers 30 institutions in $27 \mathrm{EU}$ countries (including the Supreme Audit Office in Poland, which was omitted in the first calculation of the SIFI for the year 2015). In 2017, thirty-five IFIs were distinguished in the EU, but only 21 out of the 35 were considered to be standalone bodies, while the rest were attached to or embedded in other institutions (e.g., the Estonian fiscal council attached to the Bank of Estonia ${ }^{23}$. Despite this, in accordance to the update of the SIFI values for 2015 and 2016 - the index

See L. von Trapp, L. Lienert, J. Wehner, op. cit.

22 R. Beetsma, X. Debrun, X. Fang, Y. Kim, V. Lledó, S. Mbaye, X. Zhang, op. cit., p. 5.

23 L. Jankovics, M. Sherwood, op. cit., pp. 11-12. 
was calculated for 30 institutions. The list of institutions for which the SIFI calculation was available for the year 2016 is presented in the fourth column in the table below.

TABLE 1: Fiscal institutions included in the datasets

\begin{tabular}{|c|c|c|c|}
\hline & IMF & OECD & $\mathrm{EC}$ \\
\hline 1 & 2 & 3 & 4 \\
\hline Australia & $\begin{array}{l}\text { Parliamentary Budget } \\
\text { Office (PBO) } 2012\end{array}$ & $\begin{array}{l}\text { Parliamentary Budget } \\
\text { Office (PBO) } 2012\end{array}$ & \\
\hline \multirow[t]{3}{*}{ Austria } & $\begin{array}{l}\text { Fiscal Advisory Council } \\
\text { (FISK) } 1970\end{array}$ & $\begin{array}{l}\text { Fiscal Advisory Council } \\
\text { (FISK) } 1970\end{array}$ & $\begin{array}{l}\text { Fiscal Advisory Council } \\
\text { (FISK) } 1970\end{array}$ \\
\hline & & $\begin{array}{l}\text { Parliamentary Budget } \\
\text { Office (PBO) } 2012\end{array}$ & \\
\hline & & & $\begin{array}{l}\text { Austrian Institute of } \\
\text { Economic Research } \\
\text { (WIFO) 1927**** }\end{array}$ \\
\hline \multirow[t]{3}{*}{ Belgium } & $\begin{array}{l}\text { High Council of } \\
\text { Finance - Public Sector } \\
\text { Borrowing Section } \\
\text { (HRF/CSF) } 1989\end{array}$ & & $\begin{array}{l}\text { High Council of Finance } \\
\text { - Section „Public Sector } \\
\text { Borrowing Requirement” } \\
\text { (HRF/CSF) } 1989\end{array}$ \\
\hline & & $\begin{array}{l}\text { High Council of Finance } \\
(\mathrm{HRF})^{*} 1936\end{array}$ & \\
\hline & $\begin{array}{l}\text { Federal Planning Bureau } \\
\text { (FPB) 1994*** }\end{array}$ & & $\begin{array}{l}\text { Federal Planning Bureau } \\
\text { (FPB) 1994*** }\end{array}$ \\
\hline Bulgaria & & & Fiscal Council 2015 \\
\hline \multirow[t]{2}{*}{ Canada } & $\begin{array}{l}\text { Parliamentary Budget } \\
\text { Office (PBO) } 2008\end{array}$ & $\begin{array}{l}\text { Parliamentary Budget } \\
\text { Office (PBO) } 2008\end{array}$ & \\
\hline & & $\begin{array}{l}\text { Financial Accountability } \\
\text { Office of Ontario } \\
(\text { FAO-ON) } 2015\end{array}$ & \\
\hline Chile & $\begin{array}{l}\text { Advisory Fiscal Council } \\
\text { (AFC) } 2014\end{array}$ & & \\
\hline Colombia & $\begin{array}{l}\text { Comite Consultivo para } \\
\text { la Regla Fiscal (CCRF) } \\
2012\end{array}$ & & \\
\hline
\end{tabular}




\begin{tabular}{|c|c|c|c|}
\hline 1 & 2 & 3 & 4 \\
\hline Croatia & & & $\begin{array}{l}\text { Commission on Fiscal } \\
\text { Policy } 2011^{* * * *}\end{array}$ \\
\hline Cyprus & Fiscal Council 2014 & & Fiscal Council 2014 \\
\hline Denmark & $\begin{array}{l}\text { Danish Economic } \\
\text { Council } 1962\end{array}$ & $\begin{array}{l}\text { Danish Economic } \\
\text { Council } 1962\end{array}$ & $\begin{array}{l}\text { Danish Economic } \\
\text { Council } 1962\end{array}$ \\
\hline Estonia & Fiscal Council 2014 & $\begin{array}{l}\text { Fiscal Council of Estonia } \\
2014\end{array}$ & $\begin{array}{l}\text { Estonian Fiscal Council } \\
2014\end{array}$ \\
\hline \multirow[t]{2}{*}{ Finland } & $\begin{array}{l}\text { National Audit Office of } \\
\text { Finland (NAO) } 2013\end{array}$ & $\begin{array}{l}\text { Independent Monitoring } \\
\text { and Evaluation of Fiscal } \\
\text { Policy Function } \\
\text { - National Audit Office of } \\
\text { Finland } 2013\end{array}$ & $\begin{array}{l}\text { National Audit Office } \\
\text { (Fiscal Policy Evaluation } \\
\text { Function) 2013**** }\end{array}$ \\
\hline & & $\begin{array}{l}\text { Finnish Economic Policy } \\
\text { Council (EPC) } 2014\end{array}$ & \\
\hline France & $\begin{array}{l}\text { High Council of Public } \\
\text { Finance (HPCF) } 2013\end{array}$ & $\begin{array}{l}\text { High Council of Public } \\
\text { Finance (HCFP) } 2013\end{array}$ & $\begin{array}{l}\text { High Council of Public } \\
\text { Finance (HCFP) } 2013\end{array}$ \\
\hline Georgia & $\begin{array}{l}\text { Parliamentary Budget } \\
\text { Office (PBO) } 1997\end{array}$ & & \\
\hline Germany & $\begin{array}{l}\text { Independent Advisory } \\
\text { Board to the German } \\
\text { Stability Council } 2013\end{array}$ & $\begin{array}{l}\text { Independent Advisory } \\
\text { Board to the Stability } \\
\text { Council } 2013\end{array}$ & $\begin{array}{l}\text { Independent Advisory } \\
\text { Board to the Stability } \\
\text { Council } 2013\end{array}$ \\
\hline \multirow[t]{2}{*}{ Greece } & $\begin{array}{l}\text { Parliamentary Budget } \\
\text { Office (HPBO) } 2010\end{array}$ & $\begin{array}{l}\text { Parliamentary Budget } \\
\text { Office (HPBO) } 2011\end{array}$ & \\
\hline & & $\begin{array}{l}\text { Hellenic Fiscal Council } \\
2015\end{array}$ & $\begin{array}{l}\text { Hellenic Fiscal Council } \\
2015\end{array}$ \\
\hline Hungary & $\begin{array}{l}\text { Fiscal Council (FC) } \\
2011^{* *}\end{array}$ & $\begin{array}{l}\text { Fiscal Council (FC) } \\
2011^{* *}\end{array}$ & $\begin{array}{l}\text { Fiscal Council (FC) } \\
2011^{* *}\end{array}$ \\
\hline Iceland & & $\begin{array}{l}\text { Icelandic Fiscal Council } \\
2016\end{array}$ & \\
\hline Iran & $\begin{array}{l}\text { Public Sector Directorate } \\
\text { of Parliament (Majlis) } \\
\text { Research Center } \\
\text { (PSDMRC) } 1991\end{array}$ & & \\
\hline Ireland & $\begin{array}{l}\text { Irish Fiscal Advisory } \\
\text { Council (IFAC) } 2011\end{array}$ & $\begin{array}{l}\text { Irish Fiscal Advisory } \\
\text { Council (IFAC) } 2011\end{array}$ & $\begin{array}{l}\text { Irish Fiscal Advisory } \\
\text { Council (IFAC) } 2011\end{array}$ \\
\hline
\end{tabular}


Table 1 (cont.)

\begin{tabular}{|c|c|c|c|}
\hline 1 & 2 & 3 & 4 \\
\hline & & $\begin{array}{l}\text { Oireachtas Parliamentary } \\
\text { Budget Office (PBO) } \\
2017\end{array}$ & \\
\hline Italy & $\begin{array}{l}\text { Parliamentary Budget } \\
\text { Office (PBO) } 2014\end{array}$ & $\begin{array}{l}\text { Parliamentary Budget } \\
\text { Office (PBO) } 2014\end{array}$ & $\begin{array}{l}\text { Parliamentary Budget } \\
\text { Office (PBO) } 2014\end{array}$ \\
\hline Kenya & $\begin{array}{l}\text { Parliamentary Budget } \\
\text { Office (PBO) } 2007\end{array}$ & & \\
\hline Latvia & $\begin{array}{l}\text { Fiscal Discipline Council } \\
\text { (FDC) } 2014\end{array}$ & $\begin{array}{l}\text { Fiscal Discipline Council } \\
\text { (FDC) } 2014\end{array}$ & $\begin{array}{l}\text { Fiscal Discipline Council } \\
\text { (FDC) } 2014\end{array}$ \\
\hline Lithuania & $\begin{array}{l}\text { National Audit Office } \\
\text { (NAOL) } 2015\end{array}$ & & $\begin{array}{l}\text { Budget Policy } \\
\text { Monitoring Department } \\
\text { - National Audit Office } \\
\text { of Lithuania (BPMD) } \\
2015\end{array}$ \\
\hline Luxembourg & $\begin{array}{l}\text { National Council of } \\
\text { Public Finance (CNFP) } \\
2014\end{array}$ & $\begin{array}{l}\text { National Council of } \\
\text { Public Finances (CNFP) } \\
2014\end{array}$ & $\begin{array}{l}\text { National Council of } \\
\text { Public Finance (CNFP) } \\
2014\end{array}$ \\
\hline \multirow[t]{2}{*}{ Malta } & $\begin{array}{l}\text { Malta Fiscal Advisory } \\
\text { Council (MFAC) } 2015\end{array}$ & & \\
\hline & & & $\begin{array}{l}\text { Malta Fiscal Council } \\
2015\end{array}$ \\
\hline Mexico & $\begin{array}{l}\text { Centre for Public } \\
\text { Finance Studies (CEFP) } \\
1998\end{array}$ & $\begin{array}{l}\text { Center for Public Finance } \\
\text { Studies (CEFP) } 1998\end{array}$ & \\
\hline \multirow[t]{2}{*}{ Netherlands } & $\begin{array}{l}\text { Netherlands Bureau } \\
\text { for Economic Policy } \\
\text { Analysis (CPB) } 1945\end{array}$ & $\begin{array}{l}\text { Netherlands Bureau } \\
\text { for Economic Policy } \\
\text { Analysis (CPB) } 1945\end{array}$ & $\begin{array}{l}\text { Netherlands Bureau } \\
\text { for Economic Policy } \\
\text { Analysis (CPB) } 1945\end{array}$ \\
\hline & $\begin{array}{l}\text { Raad van State (RvS) } \\
2014\end{array}$ & & $\begin{array}{l}\text { The Council of State } \\
\text { - Advisory Division } \\
\text { (RvS) } 2014\end{array}$ \\
\hline Peru & $\begin{array}{l}\text { Consejo Fiscal (CF) } \\
2015\end{array}$ & & \\
\hline Poland & & & $\begin{array}{l}\text { Supreme Audit Office } \\
\text { (NIK) } 1919 * * * *\end{array}$ \\
\hline
\end{tabular}




\begin{tabular}{|c|c|c|c|}
\hline 11 & 2 & 3 & 4 \\
\hline Portugal & $\begin{array}{l}\text { Portuguese Public } \\
\text { Finance Council (CFP) } \\
2012\end{array}$ & $\begin{array}{l}\text { Portuguese Public } \\
\text { Finance Council (CFP) } \\
2012\end{array}$ & $\begin{array}{l}\text { Portuguese Public } \\
\text { Finance Council (CFP) } \\
2012\end{array}$ \\
\hline Romania & Fiscal Council 2010 & & Fiscal Council 2010 \\
\hline Serbia & Fiscal Council 2011 & & \\
\hline $\begin{array}{l}\text { Slovak } \\
\text { Republic }\end{array}$ & $\begin{array}{l}\text { Council for Budget } \\
\text { Responsibility (CBR) } \\
2012\end{array}$ & $\begin{array}{l}\text { Council for Budget } \\
\text { Responsibility (CBR) } \\
2012\end{array}$ & $\begin{array}{l}\text { Council for Budget } \\
\text { Responsibility (CBR) } \\
2012\end{array}$ \\
\hline \multirow[t]{2}{*}{ Slovenia } & & $\begin{array}{l}\text { Slovenian Fiscal Council } \\
2017\end{array}$ & \\
\hline & & & $\begin{array}{l}\text { Institute of } \\
\text { Macroeconomic Analysis } \\
\text { and Development } \\
\text { (IMAD) 1991**** }\end{array}$ \\
\hline South Africa & $\begin{array}{l}\text { Parliamentary Budget } \\
\text { Office (PBO) } 2014\end{array}$ & & \\
\hline South Korea & $\begin{array}{l}\text { National Assembly } \\
\text { Budget Office (NABO) } \\
2003\end{array}$ & $\begin{array}{l}\text { National Assembly } \\
\text { Budget Office (NABO) } \\
2003\end{array}$ & \\
\hline Spain & $\begin{array}{l}\text { Independent Authority } \\
\text { of Fiscal Responsibility } \\
\text { (AIReF) } 2014\end{array}$ & $\begin{array}{l}\text { Independent Authority } \\
\text { of Fiscal Responsibility } \\
\text { (AIReF) } 2014\end{array}$ & $\begin{array}{l}\text { Independent Authority } \\
\text { of Fiscal Responsibility } \\
\text { (AIReF) } 2014\end{array}$ \\
\hline Sweden & $\begin{array}{l}\text { Swedish Fiscal Policy } \\
\text { Council (FPC) } 2007\end{array}$ & $\begin{array}{l}\text { Swedish Fiscal Policy } \\
\text { Council (FPC) } 2007\end{array}$ & $\begin{array}{l}\text { Swedish Fiscal Policy } \\
\text { Council (FPC) } 2007\end{array}$ \\
\hline Uganda & $\begin{array}{l}\text { Parliamentary Budget } \\
\text { Office } 2001\end{array}$ & & \\
\hline \multirow[t]{2}{*}{ UK } & $\begin{array}{l}\text { Office for Budget } \\
\text { Responsibility (OBR) } \\
2010\end{array}$ & $\begin{array}{l}\text { Office for Budget } \\
\text { Responsibility (OBR) } \\
2010\end{array}$ & $\begin{array}{l}\text { Office for Budget } \\
\text { Responsibility (OBR) } \\
2010\end{array}$ \\
\hline & & $\begin{array}{l}\text { Scottish Fiscal } \\
\text { Commission (SFC) } 2014\end{array}$ & \\
\hline US & $\begin{array}{l}\text { Congressional Budget } \\
\text { Office (CBO) } 1974\end{array}$ & $\begin{array}{l}\text { Congressional Budget } \\
\text { Office (CBO) } 1974\end{array}$ & \\
\hline EU & & $\begin{array}{l}\text { EU - European Fiscal } \\
\text { Board (EFB) } 2016\end{array}$ & \\
\hline
\end{tabular}


Table 1 (cont.)

\begin{tabular}{|l|l|l|l|}
\hline 1 & \multicolumn{1}{|c|}{2} & \multicolumn{1}{c|}{3} & \multicolumn{1}{c|}{4} \\
\hline dataset & $\begin{array}{l}\text { 39 fiscal councils } \\
\text { in 37 countries }\end{array}$ & $\begin{array}{l}\text { 32 institutions in 26 } \\
\text { OECD countries around } \\
\text { the world, and the } \\
\text { European Fiscal Board } \\
\text { (as the 33rd institution) }\end{array}$ & $\begin{array}{l}\text { 30 institutions in 27 EU } \\
\text { countries }\end{array}$ \\
\hline Last update & December 2016 & 29 June 2018 & March 2017 \\
\hline
\end{tabular}

* In Belgium, the High Council of Finance was established in 1936 but the IFI function (the Section for Public Sector Borrowing Requirements) was not established until 1989.

** In Hungary, a fiscal council was initially set up as part of the Fiscal Responsibility Law passed in 2008, but was abolished in 2010. In 2011 a new fiscal council - legally separate from the former fiscal council - was established. In the same year, this new fiscal council became embedded in the Hungarian constitution as part of Hungary's constitutional reforms.

*** Belgium. Institution was established in 1959 as "Programming Bureau". In 1994, in the wake of the fourth Belgian state reform, the Planning Bureau's name was once more changed, to the "Federal Planning Bureau".

A year (in general) denotes the year of effective start and it may differ from the date of establishment. In some cases (when the date of effective operation is not evident) the year**** denotes the year of establishment.

Acronym in brackets.

The Table was prepared based on the data available in August 2018.

S o u r c e: author's own compilation based on IMF, OECD BPO, and EC data and webpages.

\section{Independent fiscal institutions in the European Union}

The role of independent fiscal institutions ${ }^{24}$ has been increased by the Council Directive 2011/85/EU of 8 November 2011 on requirements for budgetary frameworks of the Member States ${ }^{25}$. Article 6.1(b) states that domestic numerical fiscal rules shall contain specifications related to its elements, including, among

24 As stated on the EC webpage "the definition of independent fiscal institutions has been used since 2006 for the purpose of selecting institutions present in the database and as a result it differs in certain respects from the definition of independent fiscal institutions that emerged from the new EU legal requirements gradually put in place since 2011" https://ec.europa.eu/ info/business-economy-euro/indicators-statistics/economic-databases/fiscal-governance-eumember-states/independent-fiscal-institutions_en; accessed on 31.08.2018.

25 Council Directive 2011/85/EU of 8 November 2011 on requirements for budgetary frameworks of the Member States, Official Journal of the European Union, L306. 
others: "the effective and timely monitoring of compliance with the rules, based on reliable and independent analysis carried out by independent bodies or bodies endowed with functional autonomy vis-à-vis the fiscal authorities of the Member States". Consequently, IFIs are aimed at emphasizing the impact of compliance with fiscal rules.

The EU's independent fiscal institutions create a voluntary network (the Network of EU Independent Fiscal Institutions ${ }^{26}$ which serves as a platform for meetings with budget representatives and the exchange of information and expert opinions. The Network is an example of cooperation at the supranational level. It combines the majority of EU IFIs. The Network was formally established at the 3rd informal meeting of EU IFIs held in September 2015 in Bratislava. Its aim is to support "the efforts to review and reinforce the EU fiscal framework, seeking to better exploit the synergies between rules and institutions, as well as between different levels of administration whilst respecting the principle of subsidiarity and enhancing local ownership and accountability"27. At the beginning of 2018 the Network consisted of 26 independent fiscal institutions from 24 EU countries (without the Czech Republic, Belgium, Croatia, and Poland). The Network's webpage states that in 2018, three institutions have joined ${ }^{28}$ : the Commission on Fiscal Policy (information in March 2018), the Finnish Economic Policy Council (EPC) established in 2014 (information in June 2018), the Czech National Fiscal Council (information in July 2018). The Czech independent fiscal council (Národní Rozpočtová $\operatorname{Rada}^{29}$ ) is a quite young institution. It began to operate only on 25 January, 2018 on the basis of Act No. $23 / 2017^{30}$ on the principles of budgetary responsibility. In particular, the Council's tasks are to: assess the implementation of numerical fiscal rules (e.g. the debt amount limit); monitor the evolution of public debt and the situation in public finances generally; prepare reports about the long-term sustainability of public finances and present these to the parliament; formulate opinions on the calculation of the value of the correction component which is used to adjust the actual deviation of the public sector operating result from the expected result. Although the

26 The alternative network is EUNIFI - EU Network of IFIs - established in November 2013 in order to promote the exchange of views among IFIs (see L. Jankovics, M. Sherwood, op. cit., p. 18).

27 http://www.euifis.eu/eng/home; accessed on 31.08.2018.

28 Ibidem.

29 https://unrr.cz/; accessed on 31.08.2018.

30 Ibidem. 
institution was officially established in January 2017. Its three members were nominated only in January 2018.

At present (at the end of August 2018) budgetary or fiscal councils exist in all EU countries with the exception of Poland. The councils were established on the basis of Council Directive 2011/85/EU ${ }^{31}$ and the two-pack Regulation (EU) No. 473/2013 of the European Parliament and of the Council of 21 May 2013 ${ }^{32}$, defining the two main tasks of IFIs - production or endorsement of forecasts; and monitoring of compliance with fiscal rules. In Poland, the Supreme Audit Office operates, which is an independent state audit institution whose mission is to safeguard public spending, submit an analysis of the execution of the state budget and monetary policy guidelines to the Sejm (Parliament), provide opinions on the vote of approval for the government; and publish the results of audits and annual reports on its activity ${ }^{33}$.

In September 2017 the Network announced plans to issue the European Fiscal Monitor, which was supposed to be published twice a year and involve "contributions from individual EU IFIs (or FCs) on the main events and challenges in the economies, public finances and fiscal frameworks of EU member states" ${ }^{\prime 4}$. The aim of the publication is to create a special platform to inform public opinion about the actions, role and performance of domestic IFIs. The first issue, in September 2017, included country notes provided by 15 participating institutions: Austria, Bulgaria, France, Greece, Hungary, Ireland, Latvia, Lithuania, Luxembourg, Malta, Netherlands, Portugal, Slovakia, Spain, and United Kingdom. The latest edition (July 2018) provides 24 country reports prepared by 25 institutions (in the case of Greece, by 2 institutions).

Table 2 presents the selected European FCs which were reported in the OECD dataset.

31 Council Directive 2011/85/EU of 8 November 2011on requirements...

32 Regulation (EU) no 473/2013 of the European Parliament and of the Council of 21 May 2013 on common provisions for monitoring and assessing draft budgetary plans and ensuring the correction of excessive deficit of the member states in the euro area, official journal of the European union, L140.

33 https://www.nik.gov.pl/en/about-us/; accessed on 31.08.2018.

34 See EU Independent Fiscal Institutions webpage. Retrieved from http:/www.euifis.eu/eng/ fiscal/174/european-fiscal-monitor; accessed on 12.12.2017. 


\begin{tabular}{|c|c|c|c|c|c|c|c|c|c|c|c|}
\hline & 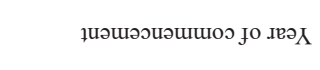 & $\beth$ & 尽 & $\stackrel{\sim}{\stackrel{2}{*}}$ & $\stackrel{2}{2}$ & ్ํ & $\stackrel{\text { ते }}{\text { ते }}$ & $\stackrel{m}{\stackrel{n}{i}}$ & $\stackrel{4}{\stackrel{4}{a}}$ & $\stackrel{m}{\bar{i}}$ & $\stackrel{m}{\stackrel{n}{i}}$ \\
\hline \multirow{6}{*}{ 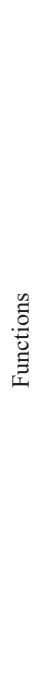 } & 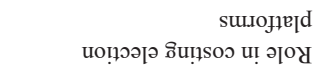 & $=$ & & & & & & & & & \\
\hline & ઠిu!̣soo Ko!̣od u! ગంy & 으 & & $\lambda$ & & & & & & & \\
\hline & 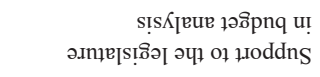 & $a$ & & $\succ$ & & & & & & & \\
\hline & 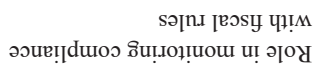 & $\infty$ & $\succ$ & & $\succ$ & $>$ & $\succ$ & $>$ & $\succ$ & $\succ$ & $\succ$ \\
\hline & 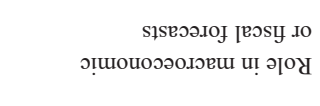 & r & $\varangle$ & & & 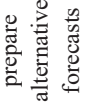 & & $\varangle$ & $\varangle$ & $\varangle$ & $\varangle$ \\
\hline & 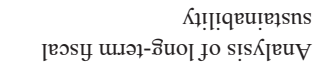 & 6 & $\succ$ & $\succ$ & $\succ$ & $\succ$ & & $>$ & $\lambda$ & & \\
\hline \multirow{3}{*}{ 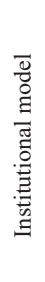 } & uo!̣nฺฺ!̣su! ฯ!̣pnV & in & & & & & & $>$ & & $\lambda$ & \\
\hline & [!’unos [eos! & t & $\lambda$ & & $\lambda$ & $>$ & $\lambda$ & & $\lambda$ & & $\lambda$ \\
\hline & 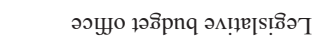 & m & & $\lambda$ & & & & & & & \\
\hline & 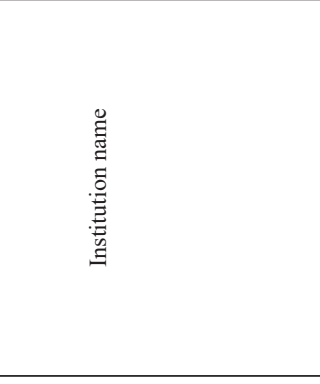 & N & 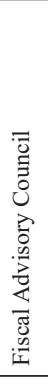 & 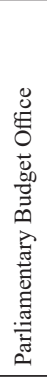 & 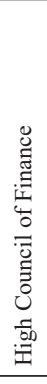 & 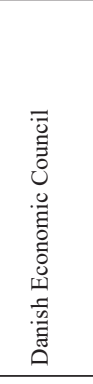 & 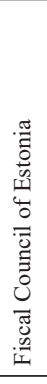 & 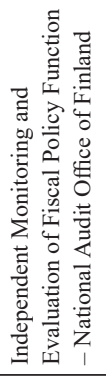 & 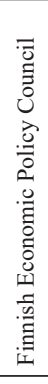 & 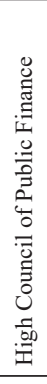 & 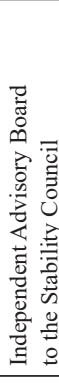 \\
\hline & $\begin{array}{l}\text { E } \\
\text { 言 }\end{array}$ & - & 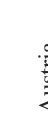 & & 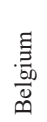 & 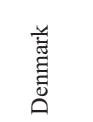 & 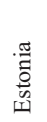 & 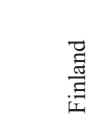 & & 若 & 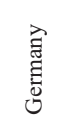 \\
\hline
\end{tabular}




\begin{tabular}{|c|c|c|c|c|c|c|c|c|c|c|c|c|c|c|c|c|c|c|}
\hline$I$ & $\overrightarrow{\bar{\sim}}$ & $\stackrel{n}{\dot{\sim}}$ & $\overline{\vec{\sim}}$ & $\overrightarrow{\vec{\sim}}$ & $\overline{\mathrm{i}}$ & $\overrightarrow{\vec{D}}$ & $\stackrel{\text { d }}{\stackrel{4}{d}}$ & $\underset{\nabla}{\stackrel{\sim}{\Delta}}$ & q & 水 & $\stackrel{\sim}{\stackrel{\sim}{\sim}}$ & $\overrightarrow{\stackrel{\sim}{े}}$ & $\stackrel{ \pm}{\stackrel{i}{*}}$ & ڤ్ర & $\stackrel{\circ}{\stackrel{\sim}{\sim}}$ & $\stackrel{\text { d }}{\stackrel{4}{d}}$ & $\stackrel{\circ}{\stackrel{\sim}{*}}$ & \\
\hline$=$ & & & & & & & & & $\lambda$ & & & & & & & & & \\
\hline 으 & & & & & $\lambda$ & $\lambda$ & & & $\lambda$ & & $\lambda$ & & & & $\succ$ & $\succ$ & & \\
\hline$a$ & $\lambda$ & & & & $\lambda$ & $\lambda$ & & & $\lambda$ & & & & & & & & & \\
\hline$\infty$ & $\lambda$ & $\lambda$ & $\lambda$ & $\lambda$ & & $\lambda$ & $\lambda$ & $>$ & & $\lambda$ & $\lambda$ & $>$ & $\lambda$ & $\lambda$ & $\lambda$ & & $\lambda$ & \\
\hline$r$ & $\varangle$ & $\varangle$ & $\varangle$ & $\varangle$ & & $\varangle$ & $\varangle$ & $\varangle$ & $\lambda$ & $\varangle$ & & & $\varangle$ & $\varangle$ & $\lambda$ & $\lambda$ & & \\
\hline 0 & & 0 & & & & $\lambda$ & 0 & $\lambda$ & $\lambda$ & $\lambda$ & $\lambda$ & & $\lambda$ & $\lambda$ & $\lambda$ & & & \\
\hline in & & & & & & & & & & & & & & & & & & $\stackrel{\infty}{\circ}$ \\
\hline$\nabla$ & & $\lambda$ & $\lambda$ & $\lambda$ & & & $\lambda$ & $>$ & $\lambda$ & $\lambda$ & $\lambda$ & $>$ & $\lambda$ & $\lambda$ & $\lambda$ & $\lambda$ & $\lambda$ & : \\
\hline$m$ & $\lambda$ & & & & $\lambda$ & $\lambda$ & & & & & & & & & & & & 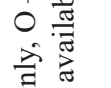 \\
\hline$N$ & 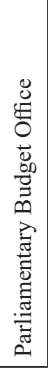 & 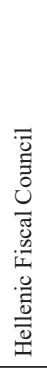 & 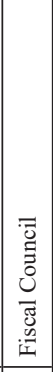 & 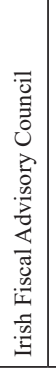 & 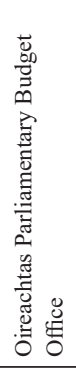 & 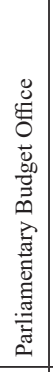 & 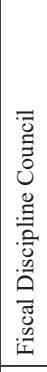 & 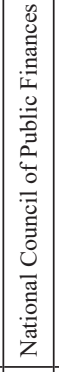 & 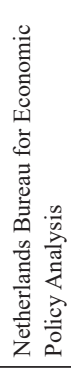 & 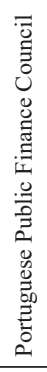 & 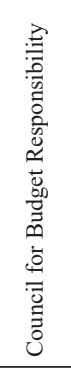 & 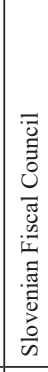 & 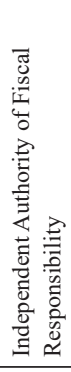 & 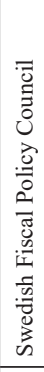 & 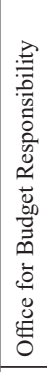 & 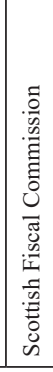 & 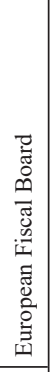 & 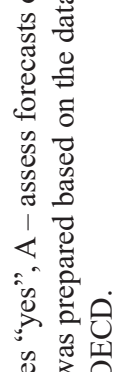 \\
\hline- & 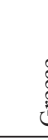 & 5 & 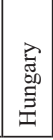 & & 胥 & 窵 & 茳 & 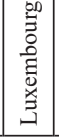 & 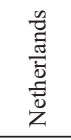 & $\begin{array}{l}\overrightarrow{3} \\
00 \\
E_{0} \\
0 \\
\end{array}$ & 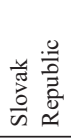 & 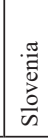 & $\begin{array}{l}\text { है } \\
\text { की }\end{array}$ & 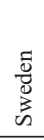 & 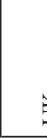 & है & 品 & 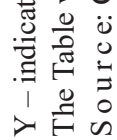 \\
\hline
\end{tabular}


In nearly $77 \%$ of the analyzed institutions (20 out of 26$)$ an FC was the institutional model of operation; in 15\% (4 institutions) - the legislative budget office; whereas in 2 institutions - audit offices. The analysis of functions was divided into six categories: analysis of long-term fiscal sustainability; the institution's role in macroeconomic or fiscal forecasts; its role in monitoring compliance with fiscal rules; direct support to the legislature in budget analysis; its role in policy costing; and its role in costing election platforms. As presented, the latest data indicates the high importance of these institutions in monitoring compliance with fiscal rules as well as providing an analysis of long-term fiscal sustainability and macroeconomic forecasts. Moreover, 21 out of the 26 institutions started to operate in the year 2010 or later.

The DG ECFIN published the first calculations of SIFI for the year 2015. The construction of the index is aimed at measuring the breadth of tasks discharged by IFIs. "The SIFI index is calculated only for 'core IFIs', based on information reported by these institutions themselves" 35 . The index covers six separate tasks of the IFI: (1) monitoring of fiscal policy and rules; (2) macroeconomic/ budgetary forecasting; (3) policy costing; (4) analysis of long-run sustainability of public finances; (5) promotion of fiscal transparency; and (6) normative recommendations on fiscal policy. Detailed information about its construction is published on the European Commission webpage ${ }^{36}$. The available series for the year 2015 - in the first measurement of the index - included 29 IFIs operating in 26 EU countries (without data for the Czech Republic due to the lack of a strictly independent fiscal institution, and without Poland). The corrected analysis (based on fine-tuned methodology) presents SIFI for 30 IFIs operating in 27 countries (including the Supreme Audit Office in Poland). The values for the index for 30 IFIs are presented in Figure 1.

35 https://ec.europa.eu/info/business-economy-euro/indicators-statistics/economic-databases/fiscalgovernance-eu-member-states/independent-fiscal-institutions_en; accessed on 31.08.2018.

36 See: Independent Fiscal Institutions. Retrieved from https://ec.europa.eu/info/business-economy-euro/indicators-statistics/economic-databases/fiscal-governance-eu-member-states/independent-fiscal-institutions_en; accessed on 12.12.2017. 
FIGURE 1: The value of SIFI for 30 European IFIs in 2015 and 2016

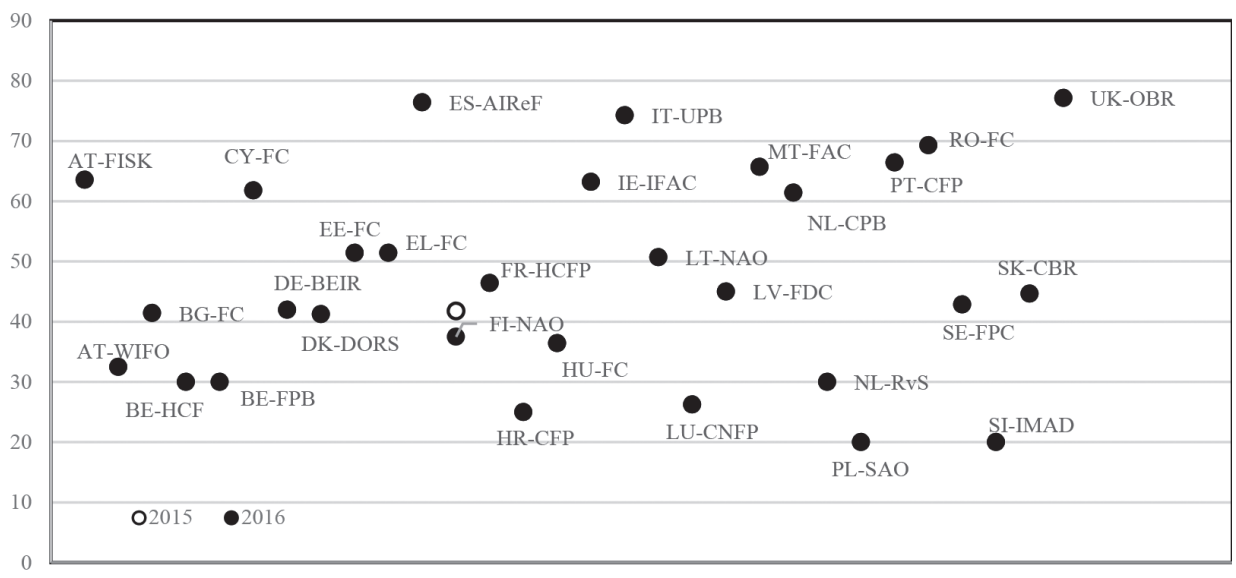

Abbreviations (the two first letters indicate the country abbreviation): AT-FISK - Austrian Fiscal Advisory Council, AT-WIFO - Austrian Institute of Economic Research, BG-FC - Fiscal Council, BE-HCF - High Council of Finance - Section „Public sector borrowing requirement”, BE-FPB - Federal Planning Bureau, CY-FC - Fiscal Council, DE-BEIR - Independent Advisory Board to the Stability Council, DK-DORS - Danish Economic Council, EE-FC - Estonian Fiscal Council, EL-FC - Hellenic Fiscal Council, ES-AIReF - Independent Authority for Fiscal Responsibility, FI-NAO - National Audit Office (Fiscal Policy Evaluation Function), FR-HCFP - High Council of Public Finances, HR-CFP - Commission on Fiscal Policy, HU-FC - Fiscal Council of Hungary, IE-IFAC - Irish Fiscal Advisory Council, IT-UPB - Parliamentary Budget Office, LT-NAO - National Audit Office (Budget Policy Monitoring Department), LU-CNFP - National Council of Public Finance, LV-FDC - Fiscal Discipline Council, MT-FAC - Malta Fiscal Council, NL-CPB - Netherlands Bureau for Economic Policy Analysis, NL-RvS - The Council of State - Advisory Division, PL-SAO - Supreme Audit Office, PT-CFP - Public Finance Council, RO-FC - Fiscal Council, SE-FPC - Swedish Fiscal Policy Council, SI-IMAD - Institute of Macroeconomic Analysis and Development, SK-CBR - Council for Budget Responsibility, UK-OBR - Office of Budget Responsibility

S o u r c e: author's own compilation based on EC data.

The average value of the index (calculated for 30 IFIs) was nearly 47.6 in 2015 and 47.5 in 2016. The institutions in Spain and the UK demonstrated the highest quality of IFI (the value of the index was nearly 77). Three countries had more than one IFI (the Netherlands, Belgium, and Austria); however, the quality of these institutions in particular countries measured by the index was quite different. The value of the index in 2016 ranged from 20 in Poland and Slovenia to nearly 77 in the UK. The value of the index was lower than the average for 17 analyzed institutions. As presented in Figure 1, the values of SIFI for almost all institutions 
in 2015 and 2016 practically overlapped, except FI-NAO - in 2016 the calculated value of the index for that institution was lower than in 2015 by 4.3 units.

At the supranational level, the advisory European Fiscal Board (EFB) operates in the EU. It was formally established in 2015 and began operating in October 2016, based on the Commission decision (EU) 2015/1937 of 21 October $2015^{37}$. The EFB, as provided in the Five Presidents' Report ${ }^{38}$, should lead to better compliance with the common fiscal rules and provide stronger coordination of countries' fiscal policies. As presented, it aims at providing a public and independent assessment of each country's budget against the concept of the EU fiscal framework. The role of the EFB is emphasized by its cooperation with the European Commission in the context of the European Semester. The guiding principles of the advisory EFB were formulated in detail in Annex 3 to the Five Presidents' Report. According to this document, the EFB should: coordinate the network of national fiscal councils and conform to the same standard of independence; advise, not implement policy - enforcing the rules should remain the task of the European Commission; formulate an economic, rather than a legal, judgement on the appropriate fiscal stance, both at national and euro area levels, against the background of EU fiscal rules; provide an ex post evaluation of how the governance framework was implemented.

As presented by Ch. Schwieter and A. Schout ${ }^{39}$, the current tasks of the EFB are limited to: evaluating how the European Commission monitors the member states; providing advice to the Commission on the prospective fiscal stance for the entire euro area rather than at the national level; providing ad-hoc advice to the Commission; and cooperating with national IFIs ${ }^{40}$. These functions of the EFB are closely related to the European Commission ${ }^{41}$ - this means that the current role and position of the EFB has been redefined, and is now largely connected with the European Commission rather than with national IFIs, in contrast to what was provided in the Five Presidents' Report. In November 2017, the EFB published its first annual report. It provides an assessment of how the

37 Official Journal of the European Union, L282.

38 European Commission, Completing Europe's Economic and Monetary Union. Report by Jean-Claude Juncker in close cooperation with Donald Tusk, Jeroen Dijsselbloem, Mario Draghi, and Martin Schulz, 2015.

39 Ch. Schwieter, A. Schout, National Fiscal Councils, the European Fiscal Board and National Productivity Boards: New EMU independent bodies without much prospect, in: Clingendael State of the Union 2018: towards better European integration, Netherlands Institute of International Relations 'Clingendael', 2018, pp. 32-39.

$40 \quad$ Ibidem, p. 36.

${ }^{41}$ Ibidem. 
SGP has been applied in recent years. Based on this evaluation the EFB issued a number of proposals, e.g., enhancing the enforcement of the country-specific numerical rules and strengthening the effectiveness of national fiscal councils $\mathrm{s}^{42}$.

As presented by Ch. Schwieter and A. Schout ${ }^{43}$, in the EU - apart from the national fiscal councils (or IFIs) and the EFB - National Productivity Boards (NPBs) may be established to monitor the microeconomic reforms relating to productivity and competitiveness. These institutions were initially described as "structurally independent bodies grounded in national legislature with the capacity to communicate publicly in a timely manner about developments as far as the productivity and competitiveness of member states is concerned" ${ }^{44}$. These institutions are derived from the concept of competiveness boards proposed by the Council of the $\mathrm{EU}^{45}$.

\section{Independent fiscal institutions and public finance in the European Union}

As presented in the previous section of this paper, the SIFI data are available only for the years 2015 and 2016. As a result, the empirical investigation of the quantitative impact of this measure of the quality of independent fiscal institutions on public finance is limited. However, it is possible to include the SIFI data in investigating the similarities among the EU countries and link these countries into groups of homogenous countries. In order to achieve this goal the cluster analysis method is used ${ }^{46}$.

The aim of the analysis is to create clusters of similar countries with respect to the performance of independent fiscal institutions viewed against the background of selected public finance data in European Union countries. Due to the lack of SIFI data for the Czech Republic, this country was not included in

\footnotetext{
European fiscal board, Annual Report 2017, https://ec.europa.eu/info/sites/info/files/2017 efb_annual_report_en_0.pdf

43 Ch. Schwieter, A. Schout, op. cit., p. 36.

44 Ibidem.

45 European Commission, Recommendation for a Council Recommendation on the establishment of National Competitiveness Boards within the Euro Area, 21 October 2015.

46 See, e.g., M. Sarstedt, E. Mooi, Cluster analysis, in: A concise guide to market research, Springer, Berlin 2011, pp. 237-284; A.W.F. Edwards, L.L. Cavalli-Sforza, A method for cluster analysis, Biometrics, 1965, pp. 362-375; A. Stanisz, Przystępny kurs statystyki z zastosowaniem STATISTICA PL na przyktadach z medycyny, Tom 3 - Analizy wielowymiarowe, StatSoft, Kraków 2007, pp. 113-163.
} 
the analysis. Moreover, due to the fact that there were two analyzed IFIs in the cases of Austria, Belgium and the Netherlands, these three countries were also not considered. As a result, only $24 \mathrm{EU}$ countries out of 28 were included in the analysis. All data refer to the year 2016. The cluster variables were as follows:

- Scope Index of Fiscal Institutions (SIFI),

- Index on the quality of medium-term budgetary frameworks (MTBFI),

- Fiscal Rule Index (FRI),

- General government consolidated gross debt to GDP ratio, in \% (DEBT),

- Change in structural budget balance, in $\%$ of potential GDP, $(\Delta \mathrm{SB})$,

- Gap between actual and potential gross domestic product, in $\%$ of potential GDP, (OGAP).

The variables and were derived from the thematic European Commission databases, whereas data for debt, structural budget balance, and output gap come from AMEO database. All fiscal data cover the sector of general government. The variables and were incorporated into the dataset in order to include the relations between independent fiscal institutions and other elements of fiscal governance in the EU (i.e., numerical fiscal rules and the medium-term budgetary frameworks). The variables and are included due to their role in determining fiscal stance. The data set also includes public debt as one of the variables reflecting the situation in public finance of a given country.

The incorporated algorithm is based on the Ward's method ${ }^{47}$ and the Euclidean squared distance. Before starting the analysis, all data were standardized. As indicated above, the original sample includes 24 countries out of the 28 EU Member States. The study was based on three separate analyses. Each of them is restricted to four cluster variables.

The first analysis takes into account four variables: SIFI $\left(x_{1}\right)$, MTBFI $\left(x_{2}\right)$, output gap $\left(x_{6}\right)$ and the change in structural budget balance $\left(x_{5}\right)$. The graphical results of this approach, in the form of a dendrogram, are presented in the left panel of Figure 2. It shows Greece as an outlier. As a result, the next analyses were prepared for 23 countries (without Greece). Figure 2 (right panel) shows the same analysis provided for these 23 countries. The decision about the number of clusters was based on the observation of the formation of an agglomeration. This procedure made it possible to create three clusters. Their structure is presented in Table 3 below.

J.H. Ward, Hierarchical grouping to optimize an objective function, Journal of the American Statistical Association, 1963/58 (301), pp. 236-244. 
FIGURE 2: Clusters for 24 EU countries (left panel) and for 23 countries (without Greece-right panel), variables: $x_{1}, x_{2}, x_{5}, x_{6}$
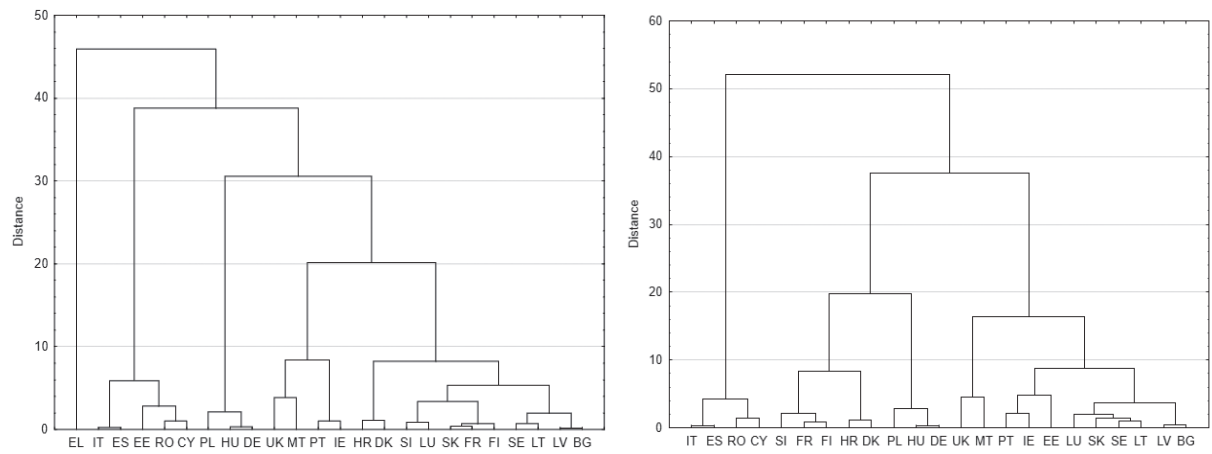

S o u r c e: author's own compilation.

The first cluster includes countries with a relatively high level of SIFIs and with countercyclical fiscal policy (in 2016 in the case of each country the fiscal stance was considered as countercyclical loosening). The $2^{\text {nd }}$ cluster identifies countries with a relatively low value of SIFI and with a procyclical fiscal policy. The group of 11 countries included in the $3^{\text {rd }}$ cluster is characterized by a relatively high value of the MTBF index.

TABLE 3: Structure of clusters for 23 countries, variables $x_{1}, x_{2}, x_{5}, x_{6}$

\begin{tabular}{|c|l|l|}
\hline \multicolumn{1}{|c|}{$1^{\text {st }}$ cluster } & \multicolumn{1}{|c|}{$2^{\text {nd }}$ cluster } & \multicolumn{1}{c|}{$3^{\text {rd }}$ cluster } \\
\hline Italy, Spain, Romania, Cyprus & $\begin{array}{l}\text { Slovenia, France, Finland, } \\
\text { Croatia, Denmark, Poland, } \\
\text { Hungary, Germany }\end{array}$ & $\begin{array}{l}\text { UK, Malta, Portugal, Ireland, } \\
\text { Estonia, Luxembourg, } \\
\text { Slovakia, Sweden, Lithuania, } \\
\text { Latvia, Bulgaria }\end{array}$ \\
\hline
\end{tabular}

S o u r c e: author's own compilation.

The second analysis takes into account four variables: $\operatorname{SIFI}\left(x_{1}\right), \Delta \mathrm{SB}\left(x_{5}\right)$, $\operatorname{OGAP}\left(x_{6}\right)$, DEBT $\left(x_{4}\right)$. The result, in form of a dendrogram, is presented in the left panel of Figure 3, whereas the structure of the clusters is presented in Table 4 below. 
FIGURE 3: Clusters for 23 EU countries, 2016 year, left panel-variables: $x_{1}, x_{4}, x_{5}, x_{6}$ right panel-variables: $x_{1}, x_{2}, x_{3}, x_{4}$
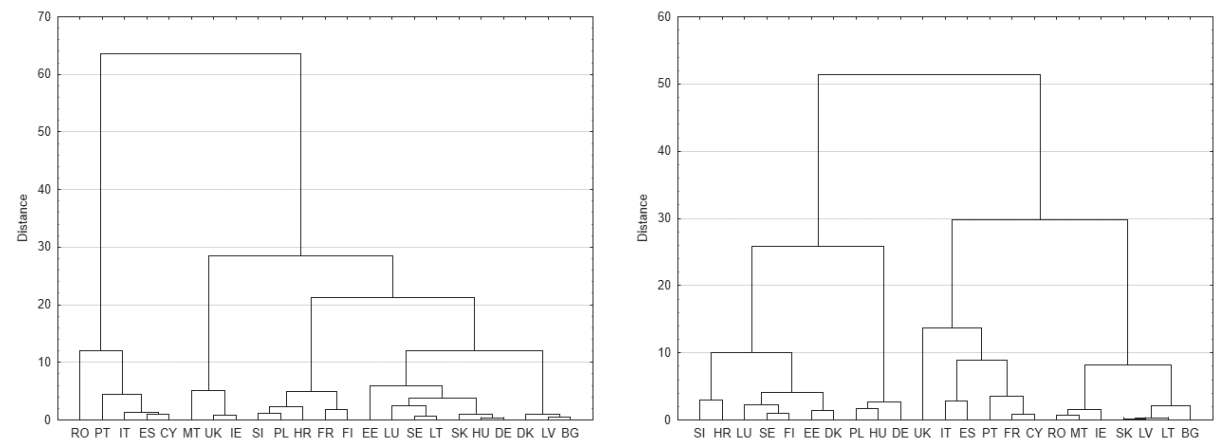

S o u r c e: author's own compilation.

The analyses of the dendrogram and features of countries makes it possible to identify four clusters, presented in the table below.

TABLE 4: Structure of clusters for 23 countries, analyzed variables: $x_{1}, x_{4}, x_{5}, x_{6}$

\begin{tabular}{|l|l|l|l|}
\hline \multicolumn{1}{|c|}{$1^{\text {st }}$ cluster } & \multicolumn{1}{|c|}{$2^{\text {nd }}$ cluster } & \multicolumn{1}{|c|}{$3^{\text {rd }}$ cluster } & \multicolumn{1}{c|}{$4^{\text {th }}$ cluster } \\
\hline $\begin{array}{l}\text { Romania, Portugal, } \\
\text { Italy, Spain, Cyprus }\end{array}$ & Malta, UK, Ireland, & $\begin{array}{l}\text { Slovenia, Poland, } \\
\text { Croatia, France, } \\
\text { Finland }\end{array}$ & $\begin{array}{l}\text { Estonia, Luxembourg, } \\
\text { Sweden, Lithuania, } \\
\text { Slovakia, Hungary, } \\
\text { Germany, Denmark, } \\
\text { Latvia, Bulgaria }\end{array}$ \\
\hline
\end{tabular}

S o u r c e: author's own compilation.

The structure of the first cluster is interesting. It includes five countries, four of which are the same as in the first cluster created in the previous analysis; moreover, it also includes Portugal. As previously, Romania, Cyprus, Spain, and Italy were characterized in 2016 by countercyclical loosening and a relatively high value of SIFI. On the other hand, Portugal, Cyprus, Italy, and Spain were the countries with the highest level of debt to GDP ratio (higher than 90\%) out of the 23 analyzed countries. Alternatively, the fiscal policy in Portugal (taking into account the measure of output gap and the value of the change in structural budget balance) was classified as procyclical tightening. Despite this, the algorithm allows us to classify Romania in the same cluster as Portugal, Spain, Italy and Cyprus. The classification adopted in the dendrogram creates 
one cluster consisting of Romania, Portugal, Spain, Italy and Cyprus, however Romania is situated away from the other four countries, (i.e. is less similar to them), which is also visible in the dendrogram where the distance of Romania to these four countries is greater. The $2^{\text {nd }}$ cluster includes countries identified as countries with countercyclical fiscal tightening and countries with a relatively high value of SIFI. The structure of the $3^{\text {rd }}$ cluster includes five countries that were similar from the point of view of fiscal policy (procyclical tightening), the lowest value of SIFI (and below the average for the 23 analyzed countries), and with general a government consolidated gross debt to GDP ratio higher than the Maastricht reference value (Poland was the exception with a debt lower than $60 \%$ of GDP - in 2016 it was nearly $54 \%$ of GDP). The last cluster is formed from countries with low debt (apart from Hungary and Germany - this is also visible on the dendrogram (Figure 3, left panel), as these two countries create a very close linkage).

The third analysis is based on four variables: $\operatorname{SIFI}\left(x_{1}\right), \operatorname{MTBFI}\left(x_{2}\right), \operatorname{FRI}\left(x_{3}\right)$ and $\operatorname{DEBT}\left(x_{4}\right)$. The results are presented in Figure 3 (right panel). The structure of the obtained clusters is presented in Table 5.

TABLE 5: Structure of clusters for 23 countries, variables: $x_{1}, x_{2}, x_{3}, x_{4}$

\begin{tabular}{|l|l|l|l|}
\hline \multicolumn{1}{|c|}{$1^{\text {st }}$ cluster } & \multicolumn{1}{|c|}{$2^{\text {nd }}$ cluster } & \multicolumn{1}{c|}{$3^{\text {rd }}$ cluster } & \multicolumn{1}{c|}{$4^{\text {th }}$ cluster } \\
\hline $\begin{array}{l}\text { Slovenia, Croatia, } \\
\text { Luxembourg, Sweden, } \\
\text { Finland, Estonia, } \\
\text { Denmark }\end{array}$ & $\begin{array}{l}\text { Poland, Hungary, } \\
\text { Germany }\end{array}$ & $\begin{array}{l}\text { UK, Italy, Spain, } \\
\text { Portugal, France, } \\
\text { Cyprus }\end{array}$ & $\begin{array}{l}\text { Romania, Malta, } \\
\text { Ireland, Slovakia, } \\
\text { Latvia, Lithuania, } \\
\text { Bulgaria }\end{array}$ \\
\hline
\end{tabular}

S our c e: author's own compilation.

The first cluster consists of seven countries with a relatively low value of SIFI and FRI and with low debt (without Slovakia and Hungary, where debt was higher than the Maastricht reference value, and the deviation of those countries is visible on the dendrogram). The $2^{\text {nd }}$ cluster refers to countries with the lowest values of MTBFI and relatively low value of SIFI. In the case of the $3^{\text {rd }}$ cluster, the value of debt ratio for the included countries was the highest out of the 23 under consideration, also the value of SIFI was relatively high. The last cluster identifies countries with a medium situation - however the values of all indexes for those countries were (in general) slightly higher than the average for the 23 countries, whereas the value of debt (except for Ireland) was lower than the Maastricht reference value. 
In 2016, countries with the highest value of SIFI (Italy, Spain, UK) were also the countries with a debt to GDP ratio higher than $80 \%$. Moreover, the fiscal policy in these three countries was countercyclical (in the UK it was countercyclical tightening, in Italy and Spain it was countercyclical loosening).

TABLE 6: Spearman's rank correlation coefficients between SIFI and other cluster variables

\begin{tabular}{|c|c|c|c|c|c|}
\hline & FRI & MTBFI & DEBT & $\Delta$ SB & OGAP \\
\hline \multirow{2}{*}{ SIFI } & 0.297 & 0.505 & 0.321 & -0.312 & 0.040 \\
& $(0.167)$ & $(0.014)$ & $(0.135)$ & $(0.147)$ & $(0.854)$ \\
\hline
\end{tabular}

$\mathrm{P}$ - value in brackets.

S o u r c e: author's own compilation.

The results presented in Table 6 show the lack of correlation between SIFI and most of the analyzed variables, except for MTBFI. As shown, in 2016 a positive and statistically significant relation between the value of SIFI and the index measuring the quality of medium-term budgetary frameworks was obtained. The lack of a statistically significant relation was observed between SIFI and FRI. Although the task of IFIs is, inter alia, to monitor compliance with fiscal rules, in 23 EU countries in 2016 the SIFI reflected a statistically significant relation with MTBFI, and while its relation with FRI was not statistically significant, it was however positive.

\section{Conclusions}

Independent fiscal institutions play an important role in many countries, due to their impact on the budgetary process and their role in fiscal frameworks. As presented, many IFIs were established as a consequence of the recent crisis, which seriously injured public finances in many countries.

The European Commission analyses the quality of IFIs and calculates the Scope Index of Fiscal Institutions (SIFI). The latest data (concerning 30 bodies representing $27 \mathrm{EU}$ countries) shows the discrepancy in the measure of the breadth of tasks discharged by each IFI - in 2016 the value of the index ranged from 20 in Poland and Slovenia to 77.14 in the UK. In August 2018, Poland was the only EU country with no operational independent fiscal council. The cluster analysis method shows that in 2016 three countries (out of the 23 under consideration) with the highest value of SIFI (Spain, Portugal, Italy) were also the countries with the highest value of the gross debt-to-GDP ratio. 
There are two main networks of IFIs in the EU - the Network of EU IFIs and EUNIFI. Their aim is to better coordinate the role of IFIs and fiscal governance and provide best practices. As presented, the latest data indicates the high importance of IFIs in monitoring compliance with fiscal rules as well as providing an analysis of long-term fiscal sustainability and macroeconomic forecasts. This is consistent with the main tasks assigned to IFIs: production or endorsement of forecasts and monitoring compliance with fiscal rules. As presented, in 2016 in the group of the 23 analyzed EU countries (e.g. 28 European Union countries without Austria, Belgium, the Czech Republic, Greece, and the Netherlands), the value of SIFI was positive and statistically significantly correlated with the value of the index on the quality of mediumterm budgetary frameworks, while the correlation with fiscal rule index was not statistically significant.

\section{References}

Commission decision (EU) 2015/1937 of 21 October 2015 establishing an independent advisory European Fiscal Board, Official Journal of the European Union, L282.

Council Directive 2011/85/EU of 8 November 2011on requirements for budgetary frameworks of the Member States, Official Journal of the European Union, L306.

Regulation (EU) no 473/2013 of the European Parliament and of the Council of 21 May 2013 on common provisions for monitoring and assessing draft budgetary plans and ensuring the correction of excessive deficit of the member states in the euro area, Official Journal of the European Union, L140.

Beetsma Roel, Debrun Xavier, Fang Xiangming, Kim Young, Lledó Victor, Mbaye Samba, Zhang Xiaoxiao, Independent Fiscal Councils: Recent Trends and Performance, IMF WP, 2018, no. WP/18/68.

Debrun Xavier, Hauner David, Kumar Manmohan S., Independent Fiscal Agencies, Journal of Economic Surveys 2009/23.

Debrun Xavier, Kinda Tidiane, Curristine Teresa, Eyraud Luc, Harris Jason, Seiwald Johann, The Functions and Impact of Fiscal Councils, IMF Policy Paper, 2013.

Debrun Xavier, Zhang Xiaoxiao, Lledó Victor, The Fiscal Council Dataset: A Primer to the 2016 Vintage, IMF, 2017.

Edwards Anthony W.F., Cavalli-Sforza Luka L., A method for cluster analysis, Biometrics, 1965, pp. 362-375.

European Commission, Completing Europe's Economic and Monetary Union. Report by JeanClaude Juncker in close cooperation with Donald Tusk, Jeroen Dijsselbloem, Mario Draghi, and Martin Schulz, 2015.

European Commission, Fiscal rules, independent institutions and medium-term budgetary frameworks, Public Finances in EMU - 2009. 
European Commission, Recommendation for a Council Recommendation on the establishment of National Competitiveness Boards within the Euro Area, 21 October 2015.

Hagemann Robert, Improving Fiscal Performance through Fiscal Councils, OECD Economics Department Working Papers 2010/829.

Jankovics László, Sherwood Monika, Independent Fiscal Institutions in the EU Member States: The Early Years, European Economy Discussion Paper 2017/067.

Kopits George, Independent Fiscal Institutions: Developing Good Practices, OECD Journal on Budgeting, 2011/11 (3).

Recommendation of the Council on Principles for Independent Fiscal Institutions, OECD, 2014.

Sarstedt Marko, Mooi Erik, Cluster analysis, in: A concise guide to market research, Springer, Berlin, Heidelberg 2011, pp. 237-284.

Schwieter Christian, Schout Adriaan, National Fiscal Councils, the European Fiscal Board and National Productivity Boards: New EMU independent bodies without much prospect, in: Clingendael State of the Union 2018: towards better European integration, Netherlands Institute of International Relations 'Clingendael', 2018, pp. 32-39.

Stanisz Andrzej, Przystepny kurs statystyki z zastosowaniem STATISTICA PL na przykładach z medycyny, Tom 3 - Analizy wielowymiarowe, StatSoft, Kraków 2007.

von Trapp Lisa, Lienert Ian, Wehner Joachim, Principles for Independent Fiscal Institutions and Case Studies, OECD Journal on Budgeting 2016/5 (2).

Ward Joe H., Hierarchical grouping to optimize an objective function, Journal of the American Statistical Association 1963/58 (301), pp. 236-244.

EU Independent Fiscal Institutions webpage, https://ec.europa.eu/info/business-economy-euro/ indicators-statistics/economic-databases/fiscal-governance-eu-member-states/independent-fiscal-institutions_en; accessed on 31.08.2018.

European fiscal board, Annual Report 2017, https://ec.europa.eu/info/sites/info/files/2017_efb_ annual_report_en_0.pdf

http://www.euifis.eu/eng/home; accessed on 31.08.2018.

https://unrr.cz/; accessed on 31.08.2018.

https://www.nik.gov.pl/en/about-us/; accessed on 31.08.2018.

What is fiscal governance?, https://ec.europa.eu/info/business-economy-euro/indicators-statistics/economic-databases/fiscal-governance-eu-member-states/what-fiscal-governance_en; accessed on 31.08.2018. 
Agata SZYMAŃSKA

\section{ROLA I ZNACZENIE NIEZALEŻNYCH INSTYTUCJI FISKALNYCH W KRAJOWYCH RAMACH BUDŻETOWYCH}

(Streszczenie)

Celem artykułu jest przedstawienie koncepcji oraz najważniejszych cech niezależnych instytucji fiskalnych. Przegląd literatury wsparto prezentacją instytucji, których cechy analizowane są przez organizacje ponadnarodowe (MFW, OECD, KE). Ponadto, w artykule przedstawiono ogólną charakterystykę europejskich niezależnych instytucji fiskalnych oraz zaprezentowano wartości indeksu skonstruowanego i obliczanego przez Komisję Europejską. Indeks ten odnosi się do zakresu zadań realizowanych przez wybrane europejskie instytucje fiskalne. W 2016 r. wartość indeksu (podawana przez Komisję Europejską dla 30 instytucji z 27 krajów UE) mieściła się w przedziale od 20 (Polska, Słowenia) do 77 (Wielka Brytania). Wyniki te wskazują na różnice w ocenie zakresu tego typu instytucji w Unii Europejskiej. Teoretyczne analizy rozszerzono o badanie powiązań między jakością niezależnych instytucji fiskalnych a sytuacją finansów publicznych w wybranych krajach Unii Europejskiej.

Słowa kluczowe: Unia Europejska; rada fiskalna; niezależna instytucja fiskalna 